\title{
Evaluation of Physical Modeling and 3-D Simulation for Planning Accropode Placement
}

\author{
Vivek Verma $^{1}$, Koshy Varghese ${ }^{1}$, A.L. Sekar ${ }^{2}$ \\ ${ }^{1}$ Dept. of Civil Eng., I.I.T. Madras, India 600 036, koshy@iitm.ac.in \\ ${ }^{2}$ Larsen \& Toubro Construction Group, India 600 089, als@1ntecc.com
}

\begin{abstract}
Accropodes are non- reinforced artificial concrete blocks used for the protection of the breakwaters and other coastal structures. There are numerous conditions that should be satisfied for the successful placement of the Accropode. In the study done two tools are developed for the understanding of the various placement conditions of Accropode. Experiments are done to compare the two tools and conventional method using text and sketches. A benefit cost analysis of the different tools is done. Results of experiments are analysed and reported. Conclusion has been drawn out of the study.
\end{abstract}

Keywords: 3D Simulation, Construction Planning, Breakwater Construction

\section{INTRODUCTION}

Accropodes are non- reinforced artificial concrete blocks utilized as protecting armour on breakwaters and costal structures. The shape of this block is complex and optimized for wave energy dissipation. However in-order to provide effective protection, the pattern of placement of these blocks have to satisfy numerous conditions. These conditions are primarily based on the spatial orientation of each block with respect to the neighboring blocks.

The blocks can weigh between 2 - $67 \mathrm{~T}$ [1] and are slung with a single rope and placed with a crane. The orientation of placement is governed by slinging direction. As the productivity of placement of these blocks contribute significantly to the completion of the project, it is critical that the block placement is planned meticulously and executed without any errors. If any error is found at a later stage, it requires the removal of the entire row of block to correct the error - the multiple handling of the blocks can cause damage and lead to delays.

On a large harbour breakwater project it was observed that planners found it complex to understand the placement conditions initially. Further, the engineers executing the plans on site

also did not clearly interpret and understand the conditions of placement. As a result there were numerous delays and rework. The objectives of this work are to (i) investigate if the planning and placement process can be made accurate and error free from the initial stages through the use of
Physical models and 3-D simulation (ii) analyse the cost-benefit of these techniques.

The experiment involved 3 groups of novice planners. The first group was allowed to learn the placement conditions using written text and sketches - the conventional method. The second group was allowed to learn the placement conditions using scaled physical models of the Accropodes and cranes. The third group was allowed to learn the placement conditions using 3D interactive graphical simulations. The understanding of each group was tested through questions on identifying errors in given placement as well as developing a placement design. A costbenefit analysis of each option was then carried out.

The paper initially discusses details on Accropodes and its placement conditions, problems faced in planning and execution. Next, the details of the experiments conducted, development of the 3-D simulation model, the results of the experiments and a comparison of the techniques are presented and discussed.

\section{ACCROPODE - DESCRIPTION}

The Accropode is a non-reinforced concrete block specially designed for the protection of riverbanks and coastal structures. Figure 1 shows the components of a typical Accropode which is designed by Sogreah Ingenierie The Accropode is stated to provide robustness and stability in a single layer to give reliable protection while being easy to fabricate, store and transport. [2] 


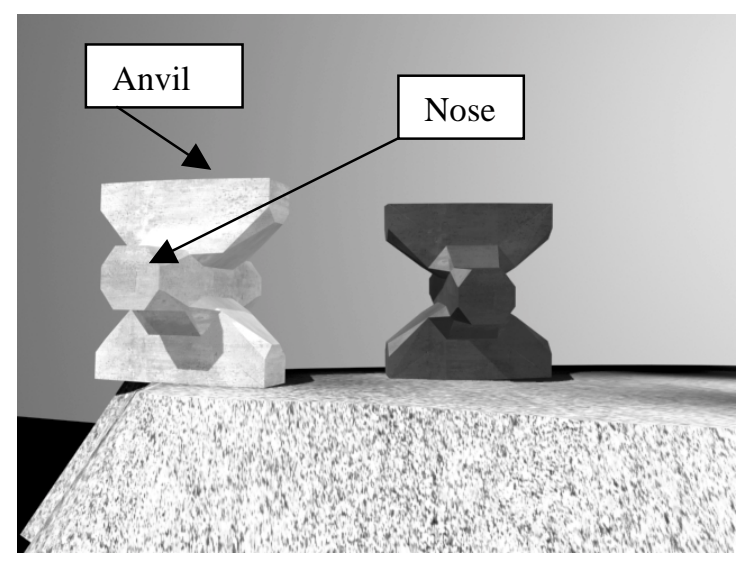

Fig. 1 Typical accropode with its components

Accropodes vary in sizes according to the level of protection required for breakwaters. Size of accropode may vary from $0.8 \mathrm{~m}^{3}(2 \mathrm{~T})$ to $28 \mathrm{~m}^{3}(67 \mathrm{~T})$ [1]

\subsection{Accropode- Design \& Placement}

In designing an Accropode layer, three factors - the size, distance and orientation have to be specified. The size of the Accropode is based on the level of protection required at a section which in-turn is governed by the coastal parameters and the breakwater layout. The distance between accropodes is fixed on the basis of their size and given by an empirical formula [1]

For a specific section, this distance remains constant along the row and column. The orientation of the Accropode is critical for the proper functioning of the structure. There are set of rules specified by Sogreah Ingenierie to determine the orientation pattern in a section [1]. These rules are:

1. Blocks are placed in a single layer.

2. Interval between the centers of gravity of two blocks in the same row and column are equal.

3. Slinging attitudes must be varied and inclination of the blocks preferred.

4. Blocks shall be placed in deliberately varied attitudes, with neighbouring blocks having different attitudes.

5. No two blocks in the same horizontal row should be in contact.

6. Each block must be in contact with the underlayer.

7. Each block must key in between two blocks on the row below.

8. Less than one third of the blocks shall have the anvil parallel to the slope. Blocks in this attitude must be distributed throughout the facing and shall not be found in groups.

9. No two adjacent blocks shall have their anvils touching.
10. Placing density shall be fixed as per drawings.

\subsection{Placement Method}

Placing the Accropodes to meet design specification is critical to the functioning of the protective layer of the breakwater. During the placement if any block is found to be placed incorrectly, rework is required to make corrections. If an error is found in a section after it is complete, it can involve the removal of many interlocking neighbouring blocks to correct the error. This will certainly affect the productivity of placement.

In the current method of placement, the breakwater is divided into number of small sections. Each of these sections is then divided into numbered grid cells. Each cell is given a number and the accropodes, which are to be placed in a particular cell, is given the corresponding numbers (say 1, 2, 3 etc.).

The section of breakwater with accropodes and corresponding grids are drawn in AutoCAD. Coordinates for each accropodes are calculated and reduced to northing and easting, which are calculated with reference to a fixed base station. These coordinates are fed into a software, which guides the placement of accropode using GPS.

The use of GPS is enabled through a GPS guided crane. In this crane, the GPS antenna mounted over the tip of its jib and the signal is sent continuously to a computer installed in crane operator's cabin. On the computer, the section grid and the position of the boom tip in relation to the grid are displayed.

When placing an Accropode, the grid number unique to the Accropode is entered into the computer. Next, the software will show the target position and the current boom-tip position. As the Accropode is slung directly below the boom-tip, the 2D position of the boom-tip corresponds with the current Accropode position. As the boom swings/luffs, the position of the Accropode shown on the screen will dynamically change according to its actual position.

The crane operator has to ensure that the current position of the Accropode is over the specified target grid before lowering it and finally releasing it.

\subsection{Rework}

The GPS enabled crane facilitates the accurate placement of an accropode in its final position. However, the orientation of the Accropode is also a critical design requirement. There are no tools to assist the operators to ensure that the orientation of placement is accurate. This is done by the human expertise of the operators and then checked by expert consultants after placement. 
After the completion of the placement in one section a check of the correctness of the accropode is carried out on the basis of ten conditions. During these checks wrongly placed accropodes are identified and marked. In order to correct the section the rework can be simple -involving one or two blocks, or very complex and involve lifting and replacing a number of blocks.

As discussed in the last section the accropodes are placed based on design specifications that ensure proper interlocking of blocks. Fig. 2 shows a typical Accropode face of a breakwater. As the blocks are interlocked, correction of a single block orientation can require the removal and replacement of an entire row. It can be seen from Fig 2 that rework can be a very complex operation, in-fact more complex than fresh placement. Further, during rework blocks can get damaged and might need total replacement.

During site visits to a breakwater construction project, it was observed that productivity of accropode placement was low as there was lot of rework in this activity. This affected the entire project productivity and exposed the contractor to high liquidated damages.

On further study and analysis it was found that the primary reason for the rework was that the placement requirements of Accropodes were not properly understood at the execution level. There is a learning curve for understanding the placement of the accropodes, as person gets more and more experience there is less chance of making error.

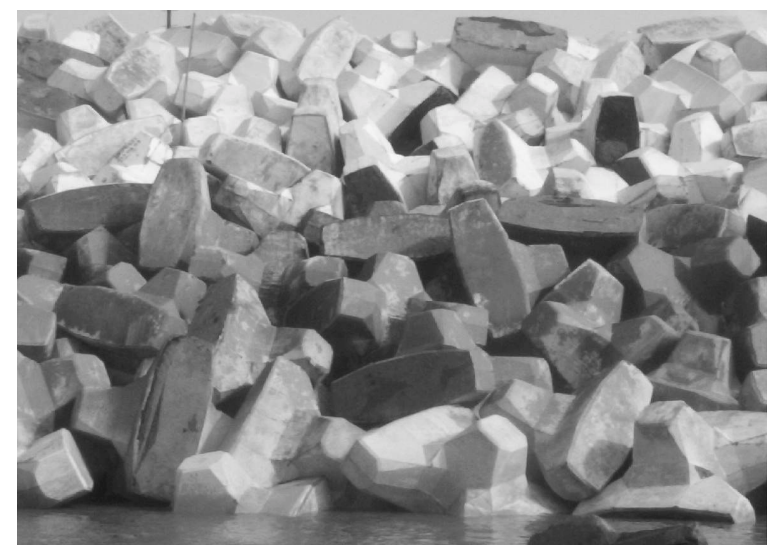

Fig. 2 Accropodes at a breakwater site

On the site visited the operators were learning on the project. This is not advisable as it takes about 2-3 months for them to learn the requirements properly. Further, as the requirements needs very good visualization and spatial capabilities, it is not easy to impart without appropriate tools.
The study done in this paper tries to flatten the learning curve by using different training tools. This study mainly deals with determining the capabilities of different training tools, to aid in improving the understanding of accropode placement design. Once placement design is understood it will reduce rework hence increase the productivity. The two tools used for this work are physical model based simulation and computer based 3D simulation. The results from these two tools are compared with the conventional method of instruction using the Text and sketches.

The following sections of this paper describe the tools, the experiments conducted, results obtained and conclusions made.

\section{PHYSICAL MODEL BASED SIMULATION}

Model trains, cars, boats, airplanes, helicopters and rockets give an opportunity to learn various phenomena which otherwise is very difficult to comprehend. Models of buildings, events, machines etc. helps deepen our understanding by providing concrete representations that engage our senses.

Model building is one way of coming to grips (sometimes literally) with aspects of our world that would otherwise be beyond our grasp. One of the tools used for the study, is physical model based simulation. In this tool, models of cranes and accropodes are used to simulate and hence aid understanding of accropode placement.

A tabletop crane model was used to imitate the movements of actual crane. The model can perform operations like swing, luff and hoist. Accropode models can be slung, lifted and placed with the help of the model crane.

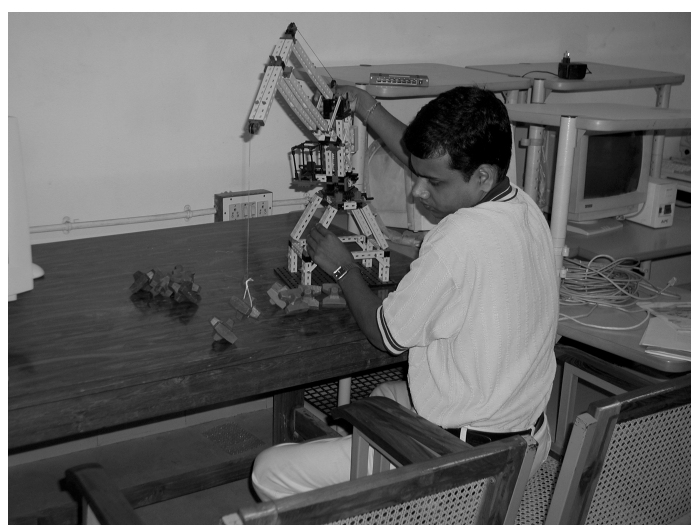

Fig. 3 Placing Accropodes With Physical Model

This helped in simulating the placement process. Scaled models of Accropodes were cast in using a custom made steel dye and high impact plastic with the help of an intrusion machine 


\section{COMPUTER BASED 3D SIMULATION}

A 3D computer based simulation of Accropode was developed showing a set of eleven accropodes placed on breakwater. Accropode geometry is modeled in software called Maya.

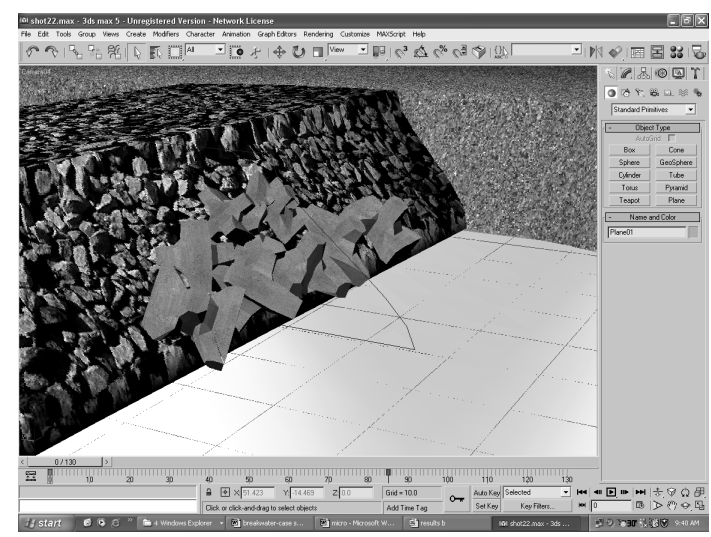

Fig. 4 Accropode Animation in 3D Studio Max

The simulation for accropode placement is modeled in 3D Studio Max [3] as shown in Fig. 6a and 6b. The advantage of such modeling is that the viewer can view the placement details as many times as required with a click of button. Further, the Accropode placement can also be viewed from different angles, to enhance the understanding on the placement orientations and slinging requirements.

\section{EXPERIMENTAL METHODOLOGY}

Purpose of the experiments was to compare the ease with which people understood placement requirements through the use of these tools.

The people who were chosen for the experiment were from mixed background. They were people with work experience from 2 to 7 years in construction industry. They had experience in supervising projects like building construction, heavy industrial and road projects.

The participants were divided into three groups. Each group was exposed to the placement requirement using:

1. Text and sketch (conventional method)

2. Physical models of Accropode and a crane model.

3. A totally computer based simulation of accropode placement.

Along with each of the above materials standard basic principles of placement of accropode were given to each participant. A single page write-up and few figures were also given to the participants of the experiment. A write up was given to provide basic information about breakwater and Accropodes.

A physical test-bed was set-up to test the understanding of the participants after they had learned the placement requirements using the respective tools. This test-bed consisted of a model breakwater slope and scaled models of Accropodes to be placed on the slope. The ability of tool to assist understanding the placement requirements was evaluated based on the accuracy with which a participant trained using a particular tool constructed the model on the test-bed.

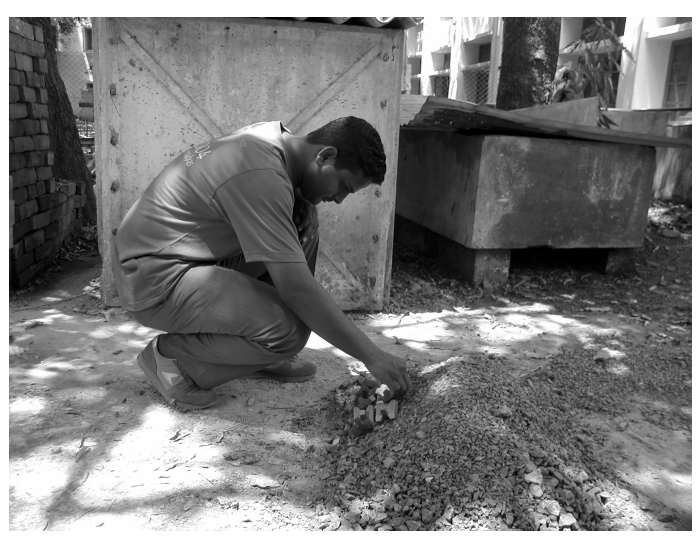

Fig. 5 Placing Accropode Model on the Test Bed

The list of the parameters for which accropode placement accuracy was checked is as follows:

1. Placement on anvil or nose

2. Number of accropodes placed on anvil

3. Attitude of the surrounding Accropodes

4. Slope

5. Contact with under layer

6. Interlocking

7. Contact with surrounding Accropodes

To conduct the experiment 15 participants were selected based on their experience and background. Each participant was given about an hour to familiarize with the assigned tools and then tested individually. After the study period, participants were asked to construct the model on the test-bed. The accropodes placed were then checked for the accuracy.

After completing the experiment with one tool participants were exposed to other two tools and asked to compare the merit of all the three tools in their view. After exposing participants to all three tools six questions were asked to find out the merit 


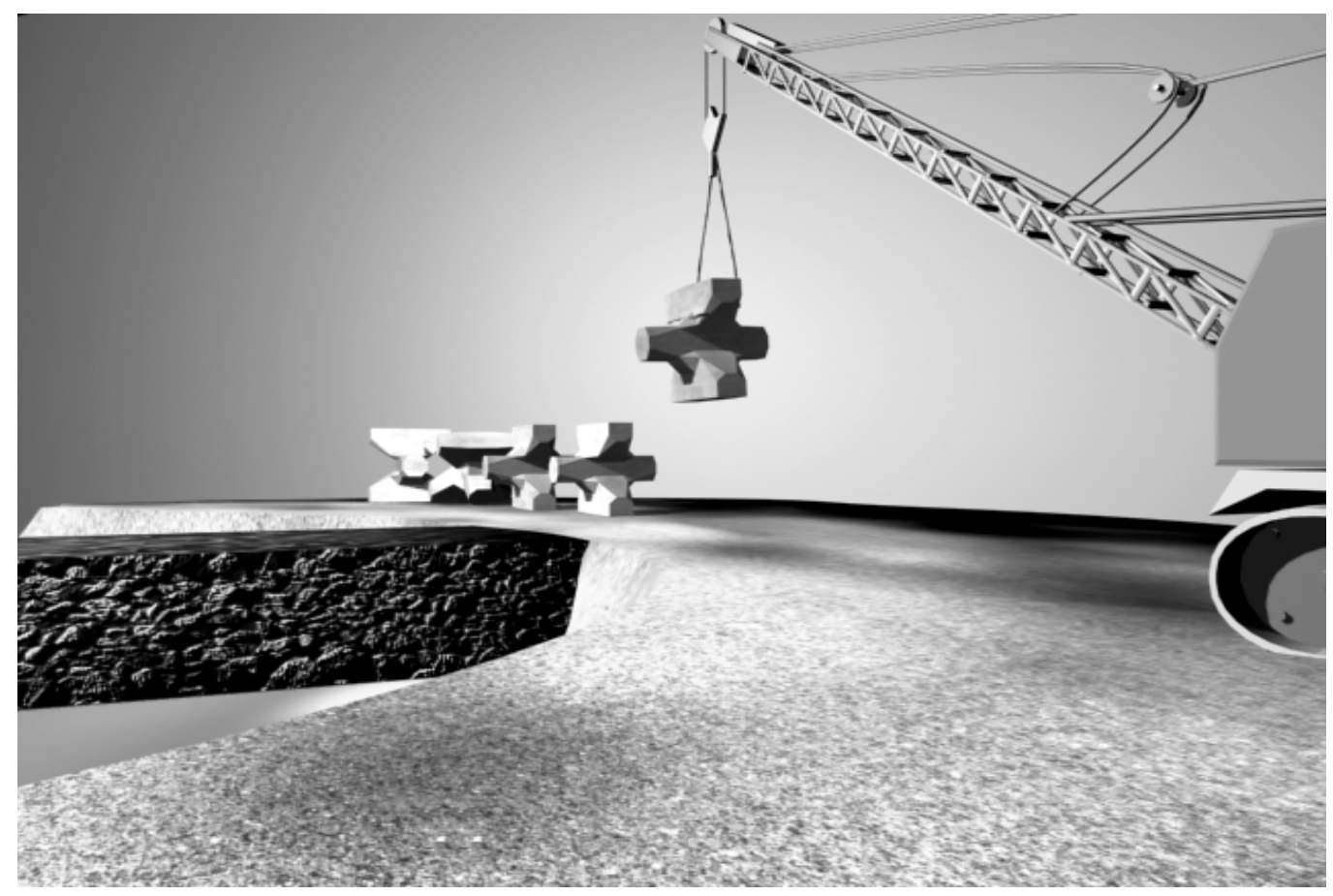

Fig 6a Computer Animation of Accropode Placement -Lifting

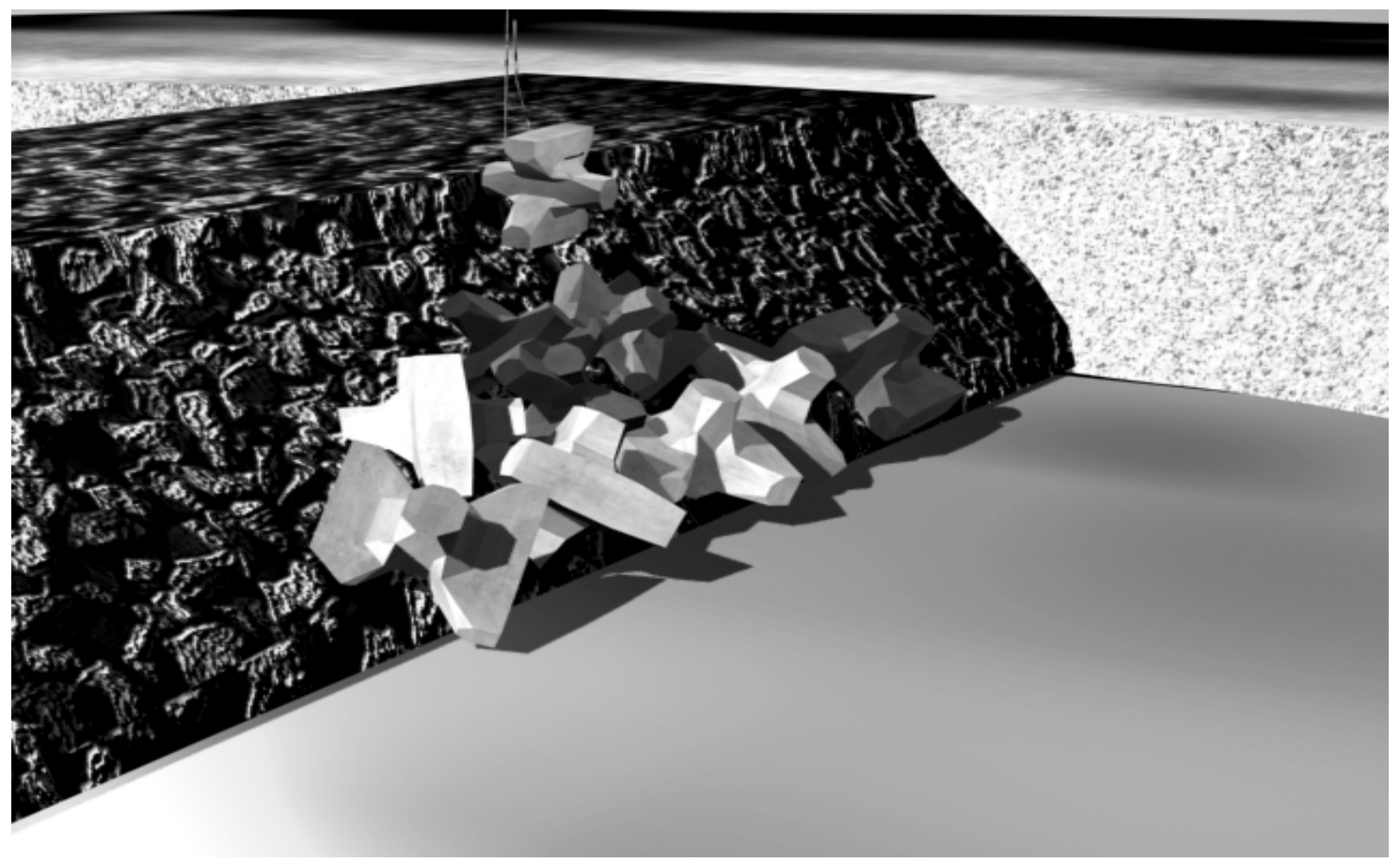

Fig 6b Computer Animation of Accropode Placement -Placing

of each tool. The questions, which were asked to participants, are listed below.

Q1. Which tool among the three was easy to understand?

Q2. Which tool gave you better understanding of the slinging positions?
Q3. Which tool helped you in visualising the total placement?

Q4. Which tool gave you better understanding of the interlocking?

Q5. Which tool gave you better understanding of the attitudes of the Accropodes? 
Q6. Which tool would you recommend for explaining the Accropode placement technique?

\section{ANALYSIS AND RESULTS}

Out of fifteen participants, five were given Text and sketches, five were given physical model, and five were given computer based 3-D simulation. None of the five given the written material were able to place accropodes in correct position. Out of five who were given physical model of crane and accropode, three were able to place the accropodes in perfect manner satisfying all the conditions. Out of the five who were given computer based $3 \mathrm{D}$ simulation of accropode placement, four were able to place it in perfect manner satisfying all the conditions.

Thus a preliminary conclusion is that computer based 3D simulation and Physical modeling are effective in communicating the accropode placement technique, while a pure paper based approach has limitations.

The results from the questions asked to the participants were also in favor of 3D simulation model. But for understanding the slinging position of the accropode, physical model based simulation was found most appropriate.

\subsection{Comparison of Tools}

In comparing the cost to develop the computer model and physical model it was found that the costs of outsourcing both to specialists were nearly the same. The charges for hardware/software usage and developers are major components of utilizing the computer model. The charges for mold and model development are the major components of the physical model. If in-house capabilities are to be developed for both it is likely that computer modeling will be cheaper as it can be shared with other requirements.

As the physical model gives the natural feeling of the placement scheme and method. It helps in understanding the various slinging procedure for accropodes. Further it shows the behavior of accropodes while they are slung and lifted. This might be valuable training for site conditions. Further, no special training or instructions is needed to train site personnel on physical modeling - they learn it naturally.

While computer modeling does not give a natural feeling of placement scheme, it is very effective in assisting the visualization of the process. The ability to display various angles simultaneously and design instructions based on common problems gives it a distinct advantage. Further, a computer animation can be stored and transferred to remote locations easily thus in terms of mobility and distributed usage also it has an advantage. However, people don't take up computer mode as naturally as they do the physical mode and there is some training required to enable them to use it effectively.

\section{CONCLUSIONS}

The placement of accropode on a breakwater face is critical activity. The orientation of the Accropode is critical for the effective functioning of the structure and as the orientation requirements are complex, there can be errors in placement. Such placement errors can lead to extensive rework, which affects the progress of the project.

A key method to minimize errors is to train the personnel on the placement requirements. The preliminary works in this study shows that both physical modeling and computer based modeling are effective in training people before the start of the project. In comparing these 2 techniques, the physical technique has a slight edge, as it is natural for the people to use. However, in future as computer capabilities improve and people get more computer savvy, the advantage of physical model will reduce.

\section{Acknowledgements}

The authors wish to thank Dr. Mangla Sundar. and Mr. Ramji of Web Studio Group, IIT Madras, for assisting in the development of the $3 \mathrm{~d}$ animation. Authors also thank Sogreah for all its support extended during the study.

\section{REFERENCES}

[1] Sogreah Brochure of general information on Accropode.

[2] Holtzhasuen A.H. \& Zwamborn J.A, (March 1991), "Stability of Accropode ${ }^{\circledR} \&$ comparison with dolosse", coastal engineering, Vol.15, Issue 1-2, Pages 59-86.

[3] "Tutorial guide of 3D Studio Max", version 5.0, Discreet Development and Developer support.

[4] Levin, R.I and Rubin, D.S. (1994) "Statistics for Management", Prentice-Hall of India, New Delhi.

[5] Thomas, H.R. and Holland, M.P (1979), "Work Sampling Programs: Comparative Analysis", Proceedings of the American Society of Civil Engineers, Vol.106, No.CO4.

[6] Xbloc single layer armour unit, http://www.dmc.nl/newsletter/DMCinfocus_11.p df (visited on 1/4/2004) 